\title{
Lyfjanotkun íslenskra aðgerðar- sjúklinga - er unnt að gera betur?
}

Um allan heim er nú leitað leiða til að bregðast við vandamálum sem tengjast aukinni langtíma notkun og misnotkun morfínskyldra verkjalyfja. Ísland er par engin undantekning. Nýleg samantekt Landlæknisembættisins sýndi fram á að fjöldi einstaklinga sem var ávísað morfínskyldum lyfjum jókst um 14\% milli áranna 2007 og 2017, og magn ávísaðra lyfja jókst um tæp 23\% á sama tímabilii. ${ }^{1}$ Nokkur vitundarvakning virðist pó hafa orðið um petta vandamál og árið 2018 dró í fyrsta skipti verulega úr ávísunum lækna á morfínskyld verkjalyf. ${ }^{2}$

Langvinn notkun kvíðastillandi lyfja af flokki benzodíazepína er jafnframt vaxandi áhyggjuefni. Víða erlendis er langvinn notkun lyfja úr pessum lyfjaflokki talin vera vaxandi vandamál sem parfnast athygli og sambærilegra leiða til að draga úr notkun hans. ${ }^{3}$ Í Bandaríkjunum koma benzodíazepínlyf við sögu í um 30\% dauðsfalla vegna ofskömmtunar morfínskyldra verkjalyfja, líklega vegna mögnunar á öndunarbælingu. ${ }^{4}$

Margra leiða hefur verið leitað til að draga úr notkun morfínskyldra lyfja á heimsvísu. Meðal pessara eru aðgerðir til að draga úr líkum á pví að sjúklingar sem undirgangast skurðaðgerðir hefji langvinna notkun morfínskyldra lyfja í kjölfaið. Erlendis hafa verið settar reglur sem takmarka magn og tímalengd ávísana á morfínskyld verkjalyf eftir bráð veikindi og skurðaðgerðir. Einnig hefur mikil aukning orðið í notkun fjölpættrar verkjameðferðar (e. multimodal analgesia) í tengslum við skurðaðgerð, sem byggir á notkun annarra lyfjaflokka og verkjameðferða.

En betur má ef duga skal. Í júnímánuði birti rannsóknarhópur minn umfangsmikla rannsókn í hinu virta tímariti JAMA Surgery á horfum íslenskra aðgerðarsjúklinga miðað við langvinna lyfjatöku peirra sex mánuði fyrir aðgerð. ${ }^{5}$ Alls tók rannsóknin til um 42 púsund aðgerða sem framkvæmdar voru á Landspítala milli 2005 og 2015. Hópar sjúklinga leystu út lyfseðla fyrir morfínskyldum lyfjum eingöngu (18\%), benzodíazepínum eingöngu (7\%) еða báðum lyfjunum (6\%) voru bornir saman við paraða viðmiðunareinstaklinga úr hópnum sem leysti ekki út lyf úr pessum lyfjaflokkum (65\%). Vönduð áhættuskorspörun var gerð sem tók meðal annars til aldurs, fylgisjúkdóma, annarrar lyfjatöku, skurðaðgerða, áhættuflokkunar og hrumleikamats.
Niðurstöðurnar sýna að að einstaklingar sem tóku bæði morfínskyld lyf og benzodíazepínlyf mánuðina fyrir skurðaðgerð höfðu hærri prjátíu daga dánartíðni (3,2\% miðað við 1,8\%) og hærri langtíma dánartíðni (áhættuhlutfall (e. hazard ratio) 1,40, 95\% vikmörk 1,22-1,64) en paraðir viðmiðunareinstaklingar. Sýnt var fram á magnsamband (e. dose-response), par sem munurinn á dánartíðni jókst eftir pví sem einstaklingar leystu út meiri lyf. Sömuleiðis leystu 66\% einstaklingar úr pessum hópi út morfínskyld lyf meira en premur mánuðum eftir skurðaðgerð, samanborið við $12 \%$ einstaklinga úr hópnum sem tók hvorki morfínskyld lyf né benzodíazepín fyrir aðgerðina. Mikilvægt er að geta pess að sýnt var fram á tengsl en ekki er hægt að fullyrða með vissu að aukin dánartíðni sé vegna töku lyfja úr pessum flokkum.

Niðurstöðurnar ættu að hvetja íslenska lækna til að sýna árvekni við ávísun lyfja og leita leiða til að aðstoða sjúklinga til að draga úr notkun lyfja úr pessum lyfjaflokkum. Skurðaðgerð er meiriháttar atburður í lífi sjúklinga okkar og getur verið hvati margvíslegra lífstílsbreytinga, par á meðal lyfjabreytinga. Með tilkomu nýrrar innskriftarmiðstöðvar svæfinga- og gjörgæsludeildar Landspítala vonumst við til pess að koma að meðferð sjúklinga nokkrum vikum fyrir valaðgerð ef kostur er. Markmiðið er að veita ráðleggingar með pví markmiði að bæta árangur og draga úr áhættu aðgerðarinnar. Við bindum miklar vonir við að nýlegt samstarfsverkefni Landspítala og heilsugæslunnar sem lýst er á öðrum stað í blaðinu verði fyrirmynd annarra sambærilegra gæðaverkefna sem gætu meðal annars tekið til langvinnrar lyfjatöku. Við vonumst eftir góðu samstarfi við heilsugæsluna til að aðstoða sameiginlega skjólstæðinga okkar við lyfja-og lífstílsbreytingar í aðdraganda skurðaðgerða.

\footnotetext{
Heimildir

1. Velferðarráðuneytið. Aðgerðir til að sporna við misnotkun lyfja sem geta valdið ávana og fikn. 2018 (https://www.stjornarradid.is/lisalib/getfile. aspx?itemid=3d1a8517-5f66-11e8-942c-005056bc530c.)

2. Landlæknisembættið. Ávísanir tauga- og geð̌lufia áriðð 2018. 2019.

3. Lembke A, Papac J, Humphreys K. Our Other Prescription Drug Problem. N Engl J Med 2018;378:693-5.

4. Jones CM, Mack KA, Paulozzi LJ. Pharmaceutical overdose deaths, United States, 2010. JAMA 2013;309:657-9.

5. Sigurdsson MI, Helgadottir S, Long TE, Helgason D, Waldron $\mathrm{NH}$, Palsson $\mathrm{R}$ et al. Association Between Preoperative Opioid and Benzodiazepine Prescription Patterns and Mortality After Noncardiac Benzodiazepine Prescription Patterns
Surgery. JAMA surgery 2019:e191652.
}

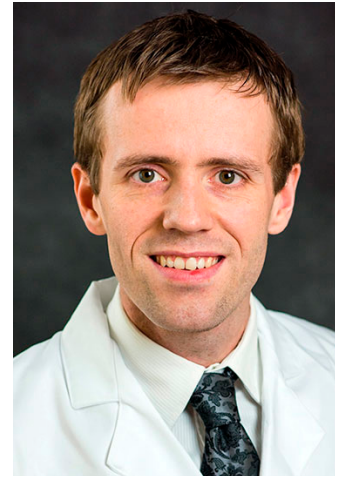

\section{Martin Ingi Sigurðsson}

Prófessor í svæfinga- og gjörgæslulækningum við Háskóla Íslands og yfirlæknir í svæfinga- og gjörgæslulækningum við aðgerðarsvið Landspítala

martiningi@gmail.com

\section{Chronic medication usage in Icelandic surgical patients - Can we do better?}

Martin Ingi Sigurðsson MD PhD, Professor of Anaesthesiology and Critical Care, University of Iceland, Chief Physician, Department of Anaesthesiology and Critical Care, Division of Perioperative Services, Landspitali University Hospital

doi.org/10.17992//bl.2019.0708.237 